\title{
Türk Dünyasını Eğitimle Birleştiren Bir Akademisyen: Prof. Dr. Turan Yazgan
}

\author{
Nihat AYCAN \\ Muğla Sitkı Koçman Üniversitesi Ĕ̆itim Fakültesi \\ nihataycan@mu.edu.tr
}

\begin{abstract}
$\ddot{O}_{z e t}$
Çalışma, insanlıkla birlikte var olan ve her toplumda önemini sürekli koruyan ĕgitimin, günümüzün bilgi çă̆ında bu önemini daha da arttırarak öne çıktı̆̆l ve toplumların gelişmişlik düzeyinin; hem ĕgitime yaptıklarl yatırım, hem ĕgitimde profesyonel olarak görev alanların, toplum merkezine yerleştirilip yerleştirilmediklerine göre belirlendiği gerçeğinden hareket eder. Ayrıca, eğitimi geliştirmek için bilime yönelenler, yer üstü ve yer altı kaynaklara veya belirli bir maddi birikime sahip oldukları kadar, eğitim için özgür ortam hazırllyorlarsa; bu toplumlar, eğitim bakımından, diğer toplumların önünde yer alırlar. Dolayısıyla, ekonomik refah düzeyi yüksek ve demokratik toplumların, eğitim bakımından da güçlü oldukları sosyal bir gerçekliktir. Türkiye, sosyo-ekonomik kaynaklart ölçüsünde eğitime önem vermiş, çeşitli evrensel eğitim modelleri deneyerek, en iyi eğitime ulaşmanın yollarını aramış, böylece bilgi çă̆ının gerisinde kalmak istememiştir. Bu yöndeki kararlılı̆̆ını, daha bilgi çă̆ı sözünün edilmediği kuruluşu yıllarında, Türk toplumuna özgü geliştirdiği bir eğitim modeliyle, zamanın Avrupa ülkelerinin dikkatini çekmiş, bazlları Türkiye'ye eğitim heyetleri gönderip, Türk Eğitim Sistemini yerinde incelemiştir. Böylesi bir eğitim deneyimi ve geleneğine sahip Türkiye, kendisiyle benzer kültür dĕgerlerini paylaşan ülke ve toplumlarla ĕ̆itim merkezli bir iş birliğine giderek, bu ülke ve toplumlarla benzer kültür değerlerini pekiştirdiği gibi, bir dizi yeni birliktelik alanları da oluşturabilir.

Bu çalışma, Türkiye’nin eğitim birikim ve deneyimini, benzer kültürü paylaştı̆̆ Türk Dünyası ülke ve topluluklarıla eğitim merkezli işbirliğinin boyutlarını, Prof. Dr. Turan Yazgan ile onun kurduğu Türk Dünyası Araştırmaları Vakfi çerçevesinde değerlendirmiştir. Değerlendirme, Prof. Dr. Turan Yazgan'ın çabasıyla, söz konusu ülke ve topluluklarda başlatılmış ĕ̆itim etkinliklerini; başlıklar ve maddeler şeklinde analiz edip, bunların tartışılması ve yorumlanmasıyla yapılmıştır. Bu çerçevede, önce eğitimin hedef kitlesi olan kişilerle ilgili eğitim etkinlikleri incelenmiş, sonra eğitimle ilgili araç-gereçler ile eğitim materyalleri ele alınmış, nihayet ĕgitimin kurumsallaşma düzeyine ulaşmış uygulamaları değerlendirilmiştir. Sonuçta, 1980 'li yillardan itibaren, Türkiye ile kültür yakınlı̆̆l olan ülke ve topluluklarda en düşük maliyetle, en verimli şekilde gerçekleştirilen eğitim uygulamalarından örnekler verilerek, Milli Ĕ̆itim Bakanlı̆̆l ve Yüksek Öğretim Kurumu'nun dikkati çekilmiştir.
\end{abstract}

Anahtar Kelimeler: eğitim, toplum, Türkiye, Türk Dünyası ülke ve toplulukları

\section{Prof. Dr. Turan Yazgan: An Academician Who Bridges The Turkish World With Education}

\begin{abstract}
This work starts off from the fact that education, which has existed along with the humanity and has preserved its importance in every society, becomes more prominent by increasing its importance even more in this information age and the societies' level of development is
\end{abstract}


determined by the investments for the education and whether these societies consider the professional personnel of education as the center of the society or not.

Moreover, societies who tend towards science to improve education get ahead of other societies in terms of education not only with underground and ground sources or their savings but also with creating a free education environment. Therefore, it is a social reality that democratic societies with high economic welfare are also powerful in terms of education.

Turkey has valued education correspondingly with its socio-economic sources and tried different universal education models and searched for the ways for best education in order not to fall behind the information age. Turkey's determination in the direction of developing education continued even in establishment years, a period when it was imposible to mention an information age, and this stituation drew the atthention of many European countries. Moreover they sent delegations to Turkey so that they could study this development in place.

With that kind of educational experience and tradition, Turkey can both reinforce the cultural values with an education-centered collaboration with countries and societies which also have similar cultural values and create new synergy fields.

This study evaluates the educational experience and accumulation of Turkey, the extent of education-centered collaboration with other Turkic countries and societies with similar culture within the scope of Prof. Dr. TuranYazgan and his Turkic Republics Research Foundation.

Evaluation process is carried out by the analysis of titles and items of educational activities in aforesaid countries with the efforts of Prof. Dr. TuranYazgan, discussions on these titles and items and making comments on them. In this context, first the educational activities concerning with the target group of education are analyzed, then educational equipment and materials are discussed and in the end education's institutionalized implementations are evaluated. In conclusion, Ministry of National Education's and the Council of Higher Education's attention is attracted by giving examples from the educational activities carried out with low costs and high efficiency in countries and societies which have a cultural relation with Turkey.

Key Words: education, society, Turkey, Turkic Countries and Societies

\section{Giriş}

Eğitim, insanın hem birlikte en az sorunla yaşamasında hem yönetme ve yönlendirilmesinde başat rol oynadığ için, devlet şeklini almış her toplumda, ya devlet tekelinde tutulmuş ya da devlet, toplum eğitiminde önemli derecede söz sahibi olmuştur. Böyle bir tutum benimseyen her devlet, varlığını bulduğu topluma, kendisini yok edecek karşıt kişilerden oluşma olanağını tanımak istemediğini, eğitim aracılığı ile bildirmiştir. Gerçekte, bir toplumu millet ve ulus yapan, o toplumun değerler sistemini iyi tanıdığı için kültür aktarımında öncü rolü üstlenip, özgür bireyler şeklinde yaşamasının ideolojik temellerini atan ve bunu pratiğe de dönüştüren, yine o toplumun aydınları ve eğitimcileridir (Kadığlu, 2005). Tanıma uygun toplum önderi olabilecek eğitim lideri, Türk toplumunda uzun bir süre yetişmemişse de, eğitim ve kültür alanında yaptıklarıyla hem Türkiye'den hem Türk Dünyası ülkelerden birçok teşekkür yazısı, şerefli profesör unvanı, fahri doktorluklar, 200 den fazla plaket, takdirnameler, onur madalyaları, ve Türkiye Cumhuriyeti Cumhurbaşkanlığı üstün hizmet ödülü sahibi olan bir eğitim lideri olarak Prof. Dr. Turan Yazgan belirtilebilir (Mamasidikov, 2005, http://www.habererk.com/haber/35330/turan-yazgan-kimdir.html).

\subsection{Araştırmanın amacı, önemi ve yöntemi}

Araştırmanın amacı, eğitim öncüsü bir Türk olarak Prof. Dr. Turan Yazgan'ın yurt dışında, özellikle Türk Dünyası ülke ve topluluklarında olmak üzere, eğitim alanında, yaptıklarını, 
bütüncü yaklaşımla değerlendirmektir. Bunun için toplumumuza, Yazgan'1 Türk toplumunun eğitimindeki örnek kişisi ya da Weber'in oluşturduğu kavram ile "ideal tip" şeklinde tanıtıp, eğitim alanındaki girişimlerine dikkat çekerek, bu alanda daha iyisinin yapılabileceği düşüncesine katkı sağlamaktır. Yazgan'ın Türk toplumu için bir ideal tip durumu ve önemi nedeniyle, çalışmaları betimsel tarama yöntemiyle ele alınmış; sosyolojik tutum ve bütüncü yaklaşımla değerlendirilmiştir.

Akademisyenliğe benzer bir çalışma ortamı ve araştırma yapma firsatı ile ekonomik yönden de çok iyi gelir sağlayan bir işi olduğu halde, ilgi duyduğu eğitim alanında kendisini geliştirmek için, Üniversiteye geçmeyi tercih eden Yazgan, eğitim idealini pratikte de gerçekleştirmek amacıyla, bir süre sonra Üniversiteden de ayrılmıştır. Yazgan'ın Üniversiteye kadrolu olarak girmek istediği sırada, onun Üniversiteden alacağı maaş, sadece ev kirasını karşılamaya yetecek kadar olup, üç çocuğu ile ev masraflarını karşılaması için ek iş yapması gerekmiştir. Buna rağmen o, maddi olanağın bu düzeydeki yetersizliğini bile önemsememiş, bir bilim insanı tavrıyla eğitim idealinin düşünsel temellerini, her kötülük ve iyilikten sorumlu tuttuğu Üniversite'de gerçekleştirmek için, Üniversite'den üç kat daha fazla maaş aldığı kamu kurumdan istifa edip, bir süreliğine Üniversiteye geçmeyi tercih etmiştir (Alper, 2005). Hayatını kar amacı olmayan bir vakıf aracığıyla, Türk Dünyası ülke ve topluluklarında her tür ve düzeyde eğitimi gerçekleştirmeye adayan, örnek bir bilim insanı, eğitimci, düşünce ve eylem insanı Yazgan'ın eğitim etkinliklerinin değerlendirilmesi önemlidir. Çünkü Yazgan, Eğitim alanında gerçekleştirdikleriyle; eğitimde, neyin en düşük maliyetle, en verimli şsekilde nasıl yapılacağının örneklerini vermiş̧tir.

\subsection{Problem cümlesi}

Türk Eğitim Sistemiyle Türkiye Türkçesinde eğitim öğretimi, Türkiye ile benzer kültürü paylaşan ülke ve topluluklarda uygulama olanağı var mıdır?, kişi ya da vakıf girişimleriyle, eğitim etkinliklerini buralarda uygulamanın başarı sansı nedir?

\section{3 İlgili literatür}

Çalışma literatürünü, Turan Yazgan'ın Türk Dünyası ülke ve topluluklarla Türkiye arasında başlattığı, eğitimle ilgili etkinlikler oluşturur. Eğitimi merkeze alıp, bu tür ilişkilerde ortaya çıkan eğitim etkinliklerini belirten çalışma; makale, anı, hatıra, röportaj şeklindeki bilgi kaynaklarından sağlanmış, birinci veya ikinci el verilerden meydana gelmiştir. Çalışmayı oluşturan çoğu literatür, Turan Yazgan hakkında özel sayı çıkartmış, İstanbul Üniversitesi Sosyal Siyaset Konferansları Dergisinde yayınlanmış yazılardır. Literatürün diğer önemli ayağı, Turan Yazgan ile ilgili internetteki siteler ve onun eğitim etkinliklerini tanıtan internet yazılarıdır. Dergi ya da internete, Turan Yazgan hakkında yazanların niteliği, onunla uzun süre Üniversite veya Türk Dünyasındaki çalışmaları sırasında birlikte olduğu iş arkadaşları, dostları, bilim insanları, yöneticiler ve basın mensuplarıdır. Örneğin, Selçuk Ünlü (2005), Turan Yazgan'ın hayatı, kişiliği, kendisi ya da kurduğu vakıf aracılığıyla eğitimle ilgili bir dizi etkinliklerinden bahsetmiştir. Yusuf Alper (2005), 13 Ekim 2004 tarihinde, Turan Yazgan ile yaptığı röportajda; onun kişisel ve aile hayatından Üniversite'deki akademik hayatına kadar geniş alanda, öğrenci, öğretim elemanı, yönetici ilişkileriyle ilgili düşüncelerini, bu ilişkilerde ortaya çıkan sorunlara yaklaşımını ve çözüm önerilerini belirtmiştir. Mustafa E. Erkal (2005), Turan Yazgan ile asistanlığından Profesörlüğüne kadar kişisel ve mesleki ilişkileriyle, kendisinin de yer aldığı Üniversite, Türk Dünyası ülke ve toplulukları ve vakıfla ilgili eğitim 
çalışmalarından söz etmiştir. M. Ahmet Gökçen (2005), Turan Yazgan ile Üniversitede birlikte olduğunda, onda gözlediği eğitim davranışlarını bildirmiştir. Muhsin Kadığlu (2005) ve Ahmet Yörük (2005), Turan Yazgan'ın ideolojik yanı ile bunun pratiğe aktarımı, Türk Milliyetçisi olarak kaygılarını ve bu kaygılarını gidermek için Türk Dünyası ülke ve topluluklarındaki eğitim ve kültür girişimlerini anlatmışlardır. Türk Dünyası ülke ve topluluklarının akil kişileri Abdilbaert Mamasidikov (2005), Vasil G. Gayfullin (2005), Ali Abbasov (2005) ve Şaripoviç Kantörö Toktomamatov (2005) Turan Yazgan'a dostum derken; onun gerçekleştirdiği eğitim etkinlikleriyle, bu etkinliklerdeki başarısından duydukları memnuniyeti dile getirmişlerdir. Sabahattin Zaim (2005), öğrencisi ve meslektaşı Turan Yazgan'1, kişiliği, sosyal ilişkileri, bilim ve eylem insanı olarak tavırlarını belirtmiştir. Turan Yazgan (1987 ve 2005), Türk Dünyası ülke ve topluluklarında gerçekleştirdiği eğitim merkezli çalışmalarındaki amacını, Türkiye için önemini açıklamıştır. Kurduğu vakıf aracılığıyla eğitimde gerçekleştirdiklerinin, ekonomik ve verimli sonuçlarını sayılarla belirtmiş; aynı yerlerde, Türkiye'nin gerçekleştirdiği eğitim etkinlikleriyle kendisinin yaptıklarını karşılaştırıp, Devlet'in maliyetli eğitim etkinliklerinin olumsuzlarının giderilmesi için, alınması gerekli önlemleri belirtmiş̧tir. Hatice Kerimov (2012), Turan Yazgan'ın ülkesindeki eğitim etkinliklerine katkılarını, örnekler vererek açıklamıştır. Nevzat Atlı̆̆ (2005), sanatçı duyarlılığı ile Turan Yazgan'1 tanıtmıştır. Murat H. Merdamert (2014), Turan Yazgan'ın bütün yönlerini, basın aracılığıyla insanlığa tanıtmıştır. Benzer tanıtım, çeşitli internet sitelerince de yapılmıştır.Örneğin,http://www.habererk.com/haber/35330/turanyazgan-kimdir.html,http://www.turan.org.tr,http://tr.vikipedia.org/wiki/Turan_Yazgan, http://www.Biyografi.net/kisiayrinti.asp?kisiid=4452.

Kenan Akın (2014), Turan Yazgan'ın Türk Dünyasında başta eğitim alanı olmak üzere, gerçekleştirdiği etkinliklerin devam ettirilmesi temennilerinde bulunmuştur. $\mathrm{Bu}$ temenni, Türkiye'nin girişimiyle, buralardaki altı ülkenin Kültür Bakanları'nın anlaşmasıyla oluşturulup, kurumlaştırılmış olan, Türk Dünyası ülke ve topluluklarıyla ortak eğitim ve kültür işbirliğini öngören TÜRKSOY, Uluslararası Türk Kültürü Teşkilatı tarafından hayata geçirilmiştir (http://www.turksoy.org.tr).

\section{Prof. Dr. Turan Yazgan'a eğitimci kimlik kazandıran hayatı, kişiliği ve eğitim etkinliklerinin değerlendirilmesi}

\subsection{Hayatı ve Kişiliği}

1938 Isparta Eğirdir doğumlu Yazgan, İlkokulu doğum yerinde, ortaokulu maddi sıkıntı nedeniyle geldiği, İstanbul Vefa Lisesi orta kısmında, en yüksek derecelerle tamamlamış; lise öğrenimine Kastamonu Fen Lisesinde parasız yatılı olarak devam etmiş ve pekiyi derece ile bitirmiştir. İstanbul Üniversitesi İktisat Fakültesi mezunu Yazgan'ın kişisel ve toplumsal yaşantısındaki ilkesi, mütevazılıktır. Dolayısıyla yüksek maaş aldığı İmar ve İskân Bakanlığı’ndaki Bölge Planlayıcısı unvanıyla lüks içinde yaşamayı düşünmemiş; bilim ve eğitimle ilgili bir hayat tarzı benimsemiştir. Bakanlıktaki görevinden istifa edip, maaşı daha düşük olan İstanbul Üniversitesi'ndeki öğretim üyeliğini tercih etmiştir. Üniversitede Akademik ve İdari görevlerde bulunan Yazgan, Üniversitesi’nin öğretim üyelerine kira gelirlerinden yaptığı ödemeyi; ögretim elemanlarının Üniversite mallarının kiralanmasiyla elde edilecek gelirden pay alamayacaklarını, bunun asli görevleri karşılı̆̆ı olmadı̆̆ını idarecilere iletse de, sonuç alamamış, konuyu yargıya taşımıştır. Yargı kararına rağmen, kendisinden başka kimsenin geri ödeme yapmaması, hatta meslektaşlarıyla Dekanın kendisiyle alay etmeleri üzerine, üniversiteden ümidini kesip, istifa etmiş ve emekliliğe ayrılmıştır. Kurduğu Türk Dünyası Araştırmaları Vâkıfı ile kendisini eğitime adayan Yazgan, 
bütün gelirini de Türk Dünyasını araştırmak için kullanmıştır. Türkiye ile ilgili milli kaygıları bulunan ve bunları da yoğun şeklide yaşamış bir eğitimci Prof. Dr. Turan Yazgan; kendi doğup büyüdüğü ülkesi dışında, Türk dünyası ülke ve topluluklarında, başta eğitim faaliyetleri olmak üzere, birçok etkinlikte sorumluluk almıştır (Erkal, 2005,Ünlü, 2005) . Yazgan, Üniversitede düşünsel temellerini attığı eğitim idealini eyleme geçirip uygulamaya koymak için, hayatını Türk Dünyası ülke ve topluluklarına adamıştır. Bunun için küçük olanaklarla, eğitim alanında büyük işler başarabileceğini örneklerle sergilemiş ve bir insanın ömrüne sığdıramayacağı çalışmayı, tek başına yapmış; bir akademisyen, düşünce ve eylem insanıdır (Gökçen, 2005, Kerimov, 2012, Yörük, 2005, http://tr.vikipedia.org/wiki/Turan_Yazgan).

Yazgan'ın bizzat kendisi ve tanıdıklarınca yapılmış kişiliği ve yaşantısı hakkındaki tanımlarda, ideal bilim insanına özgü birçok nitelik belirtilmiştir. Örneğin, samimi, idealist, ani gelişen olaylar karşısında soğukkanlı, ancak hemen uygun çözüm üreten, adil, uyumlu, sabırlı, birleştirici, ümidini hiç kaybetmeyen şeklindeki nitelikler olup; kendi aile bireylerinin de, benzer manevi özelliklere sahip olduğu belirtilmiştir. (Mamasidikov, 2005, Alper, 2005, Akın, 2012, Gökçen, 2005, Toktomamatov, 2005, Yörük, 2005, Zaim, 2005, http://www.biyografi.net/kisiayrinti.asp?kisiid= 4452).

\section{2 Ĕ̈itim etkinlikleri}

Prof. Dr. Turan Yazgan, başlangıçta iktisat biliminin sosyal güvenlik alanında uzmanlaşmış bir akademisyen iken, hayatının belirli bir döneminden sonra düşünsel ilgisini tamamen Türkiye'nin Türk Dünyasındaki ülke ve topluluklarının eğitim öğretim faaliyetleriyle; "eğitim modeli“, "eğitim programı", "eğitim maliyeti" gibi alanlarına yöneltmiş ve bu konuları oldukça geniş bir çerçevede incelemiştir. Kısaca o, iktisat biliminin kazanımlarını eğitim alanında kullanarak, maliyeti düşük ve verimli bir eğitim için, nelerin, nasıl yapılabileceğinin örneklerini, bizzat kendisi yaparak göstermiştir. Bu tutumuyla Yazgan, dünyadaki devlet ya da topluluk halindeki bütün Türkleri, eğitim çatısında birleştirmenin somut örneklerini, 1980 yılında kurduğu, Bakanlar Kurulu'nca da vergi muafiyeti tanınan, Türk Dünyası Araştırmaları Vakfı aracılığıyla gerçekleştirerek vermiştir (Yazgan, 2005). Yazgan'a göre(2005), eğitimin her düzeyinde ve çeşitli alanlarında bulunduğu girişimleri, yurt dışında benzer eğitim girişimlerinde bulunanlarınkinden farklıdır. Farklılık, kendi öncülüğündeki eğitim girişiminin Türk dünyası ile sınırlı olması ve dilinin de Türkçe olmasıdır.

Turan Yazgan'ın eğitim etkinliklerinden söz edebilmek için, önce eğitim etkinliklerinin gerçekleşmesiyle kurumlaşmasında önemli payı bulunan, Türk Dünyası Araştırmaları Vakfı değerlendirilmiş; sonra, bu Vakıf'ın katkı yaptığı eğitim etkinlikleri incelenmiştir.

\subsubsection{Türk Dünyası Araştırmaları Vakfi}

Türk Dünyası Araştırmaları Vakfı, Yazgan tarafından, 1980 'de, İstanbul'da Kurulmuştur. Amacı, kar amacı gütmeden, Türk Dünyası ile ilgili her çeşit araştırmalar yapmak, bu alanda süreli ve süresiz yayınlar çıkartmak, dil birliğini gerçekleştirecek her türden faaliyet gösteren eğitim kurumları oluşturmak, bu yönde sosyal, kültürel faaliyetler icra etmektir (Alper, 2005, Yazgan, 2005, http://www.turan.org.tr).

Bu vakıf, bazı özellikleriyle diğer vakıflardan ayrılır. Örneğin, Türkiye’deki ya da Türk 
Dünyasındaki birçok vakfın yaptığı gibi, Türk Dünyası Araştırmaları Vakfı'nın yüksek fiyatlarla eğitim olanağı sağlayıp, okulları adeta bir ticarethane haline dönüştürerek, kar etmek gibi bir amacı yoktur. Çoğu vakıf, Kar etmeyi temel ilke olarak benimsemesine rağmen, bu vakıfların açtığ 1 kurslara veya okullara giden, ciddi sayıda öğrenci vardır (Yazgan, 2005). Bu nedenle Türk Dünyası Araştırmaları Vakfı'nın amacından hareketle, Prof. Dr. Turan Yazgan'ın vakıfla birlikte eğitime yaptığı katkının değerlendirilmesi, onun eğitim alanındaki çalışmalarının arka planını da ortaya koyacaktır. Böylece Yazgan'ın eğitim idealini, yani hem Türk Dünyasındaki ülke ve topluluklarını bir eğitim etkinliği olarak, tek yazı dili Türkçede birleştirme çabasını, hem de kendisini diğer toplumlardan kültür olarak daha yakın hissettiği Türk Dünyasındaki ülke ve topluluklarının ihtiyaç duyacağı insan gücünü sağlamasına yardımcı olmasını anlayacağız. Yine bu konuyu değerlendirmekle, onun Türk Dünyasındaki ülke ve topluluklara, Türkiye'ye saygınlık kazandırma düşüncesini de açıklamış olacağız.

Prof. Dr. Turan Yazgan'ın eğitimle ilgili pratik eyleme yönelik çalışma ve uygulamalarını, alt başlıklar şeklinde ayrıntılı vermek, onun eğitimdeki statüsünü daha anlaşılır kılacağı için; onun eğitimle ilgili ekinlikleri, üç başlıkta değerlendirilmiştir. Birinci başlıkta, Yazgan'ın Türk Dünyası ülke ve topluluklarındaki aydın kişiler başta olmak üzere, toplumdaki tüm kişilere yönelik olarak gerçekleştirdiği eğitim çalışmaları değerlendirilmiştir. İkincisinde, Yazgan'ın Türk Dünyası ülke ve topluluklardaki okulların, eğitim etkinliklerini gerçekleştirdiği; eğitim materyalleri, eğitim araç ve gereçleri incelenmiştir. Üçüncüsünde ise, Yazgan'ın kendisinin başlattığı eğitim çalışmalarının, kendisi veya başka kişiye bağlı olmadan da devamını sağlayan eğitimle ilgili kurumlaştırmaları değerlendirilmiştir.

\subsubsection{Yazgan'ın Türk Dünyası ülke topluluklarındaki kişilere yönelik ĕgitim etkinlikleri}

Yazgan'ın bu başlık atındaki eğitim etkinlikleri, her yaştaki kişileri kapsamaktadır. Örneğin, Türk Dünyası ülke ve topluluklarındaki aydın kişiler öncelikli olmak üzere, eğitim etkinlikleri; çocuk, genç ve yetişkinler dâhil herkesi kapsayıcı şekilde gerçekleşmiştir. $\mathrm{Bu}$ etkinlikler, ya Türkiye'de ya da ilgili ülke veya toplulukta gerçekleştirilmiştir.

Türkiye'de gerçekleştirilmiş kişilere yönelik eğitim etkinliği, Türk Dünyası Araştırmaları Vakfı'nın çabalarıyla gerçekleşmiş̧ir. Vakıf, Türk Coğrafyasından 40 ya da 60'şar kişilik gruplar halinde oluşturulmuş öğretmenleri, kendi olanaklarıyla Türkçe öğretmek amacıyla Türkiye'ye getirilmiş ve bunların her türlü ihtiyaçlarını da yine vakıf kendisi karşılamıştır. $\mathrm{Bu}$ şekilde ilk kez Türkiye'ye getirilmiş bin civarındaki bu öğretmenler, Türkiye'de iki ay sürede, Türkiye Türkçesi ile Türk'e Türkçe Öğretme kurslarına tabi tutulmuş; kurs sonunda bunlara, Ülkelerinde Türkçe Öğretmenliği yapabilir belgesi verilmiştir (Yazgan, 2005, Abbasov, 2005, Kadıoğlu, 2005, Kerimov, 2012).

Türk Dünyası ülke ve topluluklarında gerçekleştirilmiş kişilere yönelik eğitim etkinliği, bu ülke ve topluluklarda, eğitimle ilgili etkinlikleri ilk kez başlatan eğitimci, Prof. Dr. Turan Yazgan'dır. O Türk Dünyasındaki ülke ve Topluluklarla ilk eğitim antlaşmaları yapmış, ilk konferanslar verip, seminerler başlatmıştır. İlk Kurultay toplamış, ilk eğitsel Şölenler 
düzenlemiş, ilk bilim ve sanat insanlarını Türkiye'ye davet etmiş, bu ülke ve topluluklarda ilk eğitim kurumlarını hizmete açmıştır (Kadığlu, 2005, Toktomamatov, 2005).

\subsubsection{Yazgan'ın Türk Dünyası ülke ve topluluklarındaki okullara, eğitim materyalleri, araç-gereçler sağlayarak gerçekleştirdiği eğitim etkinlikleri}

Eğitimin düşük maliyetle ve kaliteli yapılmasını hedefleyen Yazgan, bunun da çağdaş eğitim materyallerine sahip olmakla mümkün olacağının bilincindedir. Dolayısıyla okullar, modern teknolojik donanım ve malzemelerle buluşturulmuş; dil, alfabe gibi eğitimin temel araç-gereçleriyle de donatılmışlardır. Bu başlıktaki eğitimle ilgili gelişmeler, beş maddede incelenmiştir.

1.Türk Dünyası ülke ve topluluklarındaki okulların telefon ahizesinden bilgisayarlarına kadar, eğitimle ilgili her türlü araç ve gereçleri, Türk Dünyası Araştırmaları Vakfı tarafından karşılanmış ve karşılanmaya da devam edilmektedir (Yazgan, 2005)

2.Turan Yazgan'a göre, insanlar dille düşünüp, araştırıp, sorguladıklarından, Türk Dünyasında ortak dilin sağlanması çok önemlidir. Bu nedenle hiçbir toplumda olmayan farklı alfabe kullanımını, Türk Dünyası ülke ve Topluluklarında da gerçekleştirmek istemiş ve farklı coğrafyalardaki Türklerin otuz ayrı alfabe kullanımını sonlandırıp, onları Türkiye Türkçesinde birleşmek için girişim başlatmıştır. Böylece o, dilde birlik ilkesini uygulamak istetmiştir. Düşünme diline çok önem verilmesini isteyen Yazgan, Türkler alfabe ile bölünmüş, alfabe ile sömürülmüş̧ür. Dünya'da hiçbir dil yoktur ki ikinci bir alfabesi olsun. Türk Dünyası da bir alfabe ile buluşmalı diyerek, hayatının en büyük mücadelesini alfabe birliği konusunda verdiğini belirtmiştir (Alper, 2005, Kadığlu, 2005, Yörük 2005). Ancak söz konusu eğitim ilkesini uygulamaya koymanın kolay olmadığını belirten Yazgan, bu girişimin daha başlangıcında, birç̧ok olumsuzluklarla karşı karşıya kaldığından söz etmiştir. Buna rağmen Yazgan, Türk ülke ve topluluklarına, bir milyon Türk Alfabesini Vakıf olanaklarıyla bastırıp göndermeyi gerçekleştirmiştir. Azerbaycan'a Elçibey'in Cumhurbaşkanlığı döneminde gönderilenler, Azerbaycan'daki okullarda ders kitabı olarak okutulmasına karar verilmiştir. Ancak Yazgan'a göre (2005), bilimsel toplantı ve kongrelerde, Rusya ve İran'a özgü yaklaşımlarının genel kabul görmesi nedeniyle, alfabe alanında istenilen düzeyde başarı sağlanamamıştır.

3.Yazgan, Türk şivesiyle İngilizce ve Türkçe konuşmayı sağlayan, Türk Dünyası Konuşma Kılavuzu'nu çıkarmıştır. Çünkü Yazgan'a göre, dil; düşünmedir. Türk çocukları, resmi dil Türkçe ile arar, sorar, yapar ve yaratır. Aksi halde, düşünmekten mahrum insanlara hangi düzeyde eğitim verirseniz verin, sürü olur, birilerinin arkasindan gider (Alper, 2005).

4.Yazgan'a göre Türk dili, eğitim dili olmalıdır. Bunun üzerine ısrarla gidilmediği için, Türkiye gelişememiş, üstelik git gide yabancı ülkelerin boyunduruğu altına girmektedir. Çükü yabancı dili ne kadar ögrretirseniz öğretin, düşünme dili haline getiremezsiniz. Dil düşünmenin, aramanın, bulmanın ve çözmenin vasıtasıdır. Yabancı dil ise, bilgiye ulaşma dilidir.(Alper, 2005).

5.Azerbaycan'daki Bakü Atatürk Lisesinin bina dışındaki lise, tümüyle Türk Dünyası Araştırmaları Vakfı'na ait olduğundan; Türkiye'den geleceklerle, yerel olarak sağlanacak öğretmenlerin seçimi ve bunlarla ilgili bürokratik işleri takip edip sonuçlandırmak vakfa aittir. Diğger okulların sadece araçgereç masrafları vakıfça karşılanırken, Azerbaycan'daki lisenin tüm bakım, onarımı ile araç-gereç masrafları vakıf tarafından karşılandığı için, lise maliyetli olmaktadır. Ancak bu okulun kontrolü, tamamen vakfa aittir. Türk Dünyası ülkelerinde eğitim yapan beş lise, vakıf şartları uygun oldukça Bakü Atatürk Lisesi statüsüne geçeceklerdir, Yazgan'a göre(2005), böyle bir statü değişikliğine, bu liselerin kendileri de gönüllüdür.

\subsubsection{Yazgan'ın Türk Dünyası ülke ve topluluklarında başlattığı eğitimi kurumsallaştırma}




\section{etkinlikleri}

Yazgan'ın Türk Dünyası ülke ve topluluklarında ilk kez gerçekleştirdiği eğitim etkinliklerinin tamamına yakını, Türk Dünyası Araştırmaları Vakfı tarafından uygulanmıştır. Böylece etkinliklerin yapılması, kişiyle sınırlı olmaktan çıkıp, devamlılık kazandığı için kurumsallaşmıştır. Eğitimde kurumsallaşma denildiğinde, eğitim etkinliklerinin ilk yapılmaya başladığ 1 andan, günümüze dek yapılmalarına devam edilen, eğitimle ilgili her türden etkinlikler anlaşılır. $\mathrm{Bu}$ anlamda, eğitim etkinlikleri de, Türk Dünyası Araştırmaları Vakfı tarafında yapılmaya başlandığı andan itibaren süreklilik kazanıp kurumsallaşmıştır. Yazgan ile birlikte yapılmaya başlanan, günümüze kadar da devam edip süreklilik kazanarak kurumsallaşan eğitim etkinlikleri, on beş maddede belirtilmiştir.

1.Her yıl başkanlığını bir Türk Dünyası ülkesi veya topluluğunun üstlendiği, Türkçülük, Demokrasi ve Insan Hakları, Serbest Piyasa Ekonomisi gibi konuların ele alındığı, sonradan adı Dünya Türkleri Asamblesi olarak değiştirilen, Türk Halklarl Asamblesi, 1997'de kurulmuştur(Kadığlu, 2005). Asamble, varlığını günümüze dek sürdürerek devamlılık kazandığı için kurumsallaşmıştır.

2.Türk Dünyası ülke ve topluluklarındaki eğitim türüne göre kurumsallaşma, Türk Dünyası Kültür Merkezleri, Türk Dünyası Liseleri ve Türk Dünyası Yüksek Öğretim Kurumları şeklindedir. Buralardaki Yüksek Öğretim Merkezleri'nde Türk Dili Bölümleri, Fakülteler oluşturmuş ve bunlar da aynı nedenle kurumsallaşmıştır. 1990'da Azerbaycan ile ilk eğitim antlaşması imzalanmış, 1991'de sonradan Fakülte haline dönüşen, denkliği YÖK tarafından da onaylanmış İşletme Enstitüsü, bölge öğrencilerine parasız eğitim verecek şekilde kurulmuştur. Sonra, Meslek Yüksekokulları, Türk Dili ve Edebiyatı Bölümleri oluşturulmuştur. Kısaca Türk Dünyası Araştırmaları Vakfı'nın, Tercümanlık ve Bilgisayar Meslek Yüksekokulu, Türk Dili ve Edebiyatı Bölümleri, Fakülteler olmak üzere üç tür yüksek öğretim kurumu vardır. Pedagoji Üniversiteleri bünyesindeki Türk Dili Bölümleri, Türkiye Türkçesi Öğretmeni yetişmektedir (Yazgan, 2005). Bu tür eğitim hizmetleri, geçmişten günümüze, vakıf tarafından verilerek devamlılık kazandığı için kurumsallaşmıştır.

3.Azerbaycan ve Kırgızistan'da, ülkenin ihtiyaç duyduğu insan kaynağını karşılamayı amaçlayan, Yazgan'ın kurduğu iki Fakülte, eğitim kurumu vardır (Mamasidikov, 2005). Aynı yerlerde Türkiye Devleti'ne ait, Yesevi Üniversitesi ve Manas Üniversitesi olmak üzere, iki tane Üniversite bulunur. Yazgan, Devlet Üniversitelerin Türkiye'ye maliyeti ile Türk Dünyası Araştırmaları Vakfı'nın Fakülte ve Lise harcama maliyetlerinin ayrıntılı analizini yapıp, dolar bazında da karşılaştırmasını yapmıştır. Devlet Üniversitelerine yapılan harcama ile Bakü'deki Atatürk Lisesi büyüklüğünde 81 Anadolu Lisesi, 240 Türk Dünyası Atatürk Lisesi ya da 180 Fakülte'nin açılabileceğini, harcama rakamlarını tek tek belirterek, karşılaştırmasını ayrıntılı bir şekilde belirtmiştir (Alper, 2005).

4.Yazgan'ın eğitim kurumlarından liselerin açılış yerlerini bile özenle seçmesi, onların sürekli işlevsel olmasını ve kurumsallaşmasını sağlamıştır. Örneğin, Türkistan kadar popüler olmasa da, bundan daha merkezi konuma sahip ve nüfusça da daha büyük olan Kentav şehrinde, sonradan adı Kentav Atatürk Lisesi olarak değiştirilen, Kentav Yesevi Lisesi açılırken; benzer gerekçe ile Celalabat, Çallı, Arçaa’ya lise açılmıştır (Yazgan, 2005).

5.Çalışmada tanıtılan çeşitli düzeydeki eğitim kurumları, bölge öğrencilerine parasız eğitim vermekte, yoksul ve başarılı olanlara, Türk Dünyası Araştırmaları Vakfı tarafinda yatılılık ya da burs sağlanmakta; spor kıyafetleriyle malzemeleri ve ders kitapları da sürekli parasız verilmektedir (Yazgan, 2005, Mamasidikov, 2005). Dolayısıyla bu alanda da kurumsallaşma sağlanmıştır.

6.Yazgan'ın eğitim etkinliklerini bireysellikten kurtarıp kurumsallaştırması, Türkiye Cumhuriyeti'ne de esin kaynağı olmuş ve bir eğitim kurumu meydana getirilmiştir. Örneğin, Türk Dünyası'nın altı bağımsız ülkesi, Azerbaycan, Kazakistan, Kırgızistan, Özbekistan, Türkiye ve Türkmenistan'ın Kültür Bakanları, 1992'de İstanbul ve Bakü'de bir araya gelerek kültürel işbirliği yapmayı kararlaştırmışlardır. Kültür Bakanları 1993'de Almatı'da yaptıkları toplantıda, antlaşma imzalayıp, 
2009'da, adı Uluslararası Türk Kültürü Teşkilatı olan TÜRKSOY' u kurmuştur. Sonradan bu kuruluşa gözlemci üye olarak KKTC, Rus Federasyonu'na bağlı Altay, Başkurdistan, Hakas, Saha(Yakut), Tataristan, Tiva ve Moldova Cumhuriyeti' deki Gagauz Yeri özerk bölgesi gibi Türk toplulukları da katılmıştır. TÜRKSOY'da ev sahibi ülke Türkiye, resmi dil Türkçe, yönetim merkezi Ankara'dır. Ülkelerle topluluklar, birbirilerinin iç ve dlş politikalarına karışmayıp, temel insan hak ve özgürlüklerinin korunması ilkesini esas almış; böylece TÜRKSOY, bölgesinde UNESCO görevi üstlenmiş ve Türk Dili konuşan ülkelerde Milli Diriliş, Devlet Yapılanması ve Demokratikleşme sürecine katkl yapmaktadır. (http://www.turksoy.org.tr)

7.Yazgan, Türk Dünyası ülke ve topluluklarında ortak zevk ve tercihler oluşturmak için, müzik eğitimiyle ilgili etkinliklerin yapılmasını da Türk Dünyası Araştırmaları Vakfı'na devrettiği için, bu etkinlikler de kurumsallaşmıştır. Örneğin, Türk Dünyasından Sesler Korosu'nu kuran Yazgan, sanatçıları teşvik ve himaye etmiş, koronun kaset ve CD'lerini tüm Türklere ulaştırmıştır (Atlığ, 2005).

8.Yazgan, ikisi Tataristan'da olmak üzere, sekiz merkezde (Çuvaşistan, Tataristan, Makedonya, Kosova, Gagauz Yeri, Bulgaristan, Hasaysa) yaygın eğitim kurumu olarak faaliyet gösteren ve Türkiye ile köprü görevi yapan, Türk Dünyası Kültür Merkezleri günümüze kadar gelerek devamlılık kazandıklarından kurumsallaşmışlardır. Bu kurumlar, bulundukları yerlerin bilim insanları, yazarları ve medyası ile Türkiye arasındaki köprü görevinde, bir dizi eğitim ve kültür etkinlikleri gerçekleştirmişlerdir. Örneğin, Türkiye Lehçesi kursları, Türk Sazı'nın öğretilmesi, İftar, Bayram Yemekleri, mahallin ve Türkiye'nin Milli Bayramları'nın kutlanması, Türk Dünyası Büyüklerini Anma Günü törenlerinin düzenlenmesi, Nevruz Kutlamaları, ülke çapında eğitim yarışmaları yapılaması ve başarılı olanlara, Türk Dünyası Araştırmaları Vakfı'nın olanaklarıyla Türkiye'de tatil yapmalarının sağlanması gibi (Yazgan, 2005).

9 Vakıf, kız ve erkek öğrencilerin barınma ihtiyaçlarını karşılamak için, okullara yurtlar yapmaktadır (Yazgan, 2005). Eğitime destek etkinliği bu durum, Türk Dünyası Araştırmaları Vakfı aracığı ile gerçekleştiği için, devamlılık kazanıp kurumsallaşmıştır. Örneğin, Türk Dünyası Atatürk Kız Yurdu.

10.Yazgan'ın Türk Dünyası ülke ve topluluklardaki eğitimle ilgili ilk etkinliklerinden bir diğeri, bu ülke ve topluluklardaki çocukları, eğitsel ve kültürel oyunlarla bir araya getirmedir. Bu amaç için Türkiye'ye gelecek çocukların tespiti ile onların geliş gidişindeki bürokratik tüm işler, Türk Dünyası Araştırmaları Vakfı'nca takip edilmektedir (Yazgan, 2005). Kısaca, Yazgan girişimiyle 1994'ten itibaren ilk kez yapılmaya başlanan, sonraları TRT tarafından gerçekleştirilmeye devam edilen ve bu yıl da 20.si kutlanacak olan Türk Dünyası Çocuk Şöleni, her yıl yapılan bir eğitim, kültür etkinliği haline gelerek kurumsallaşmıştır (http://www.turan.org.tr).

11.Yazgan'ın çocuklara yönelik olarak 2003 yılında başlattığ 1 ve her yıl kutlamaları yapıldığ 1 için kurumsallaşan eğitim etkinliği, Türk Dünyası Çocukları Ses Yarlşması'dır (http://www.turan.org.tr).

12.Yazgan'ın, 1980 yılında, Türk Dünyası Araştırma Vakfi Gençlik Kolları adıyla kurduğu, 1992 yılında adını Dünya Türk Gençleri Birliği olarak değiştiren ve günümüze kadar gelerek kurumsallaşan Dünya Türk Gençleri Birliği, çalışmalarını; akılcılık esasıyla yürütmek, misyonunu; Türk Dünyası Araştırmaları Vakfı çatısı altında, Turan Yazgan'ın açtı̆̆ yolda, Dilde, Fikirde, Işste Birlik ülküsüyle, Türk Dünyasının birliği ve dirliği için çalışmak şeklinde belirlemiştir. Misyonu doğrulusunda, konferans, panel gibi bir dizi eğitim etkinlikleri gerçekleştirilmektedir (http://www.turan.org.tr).

13.Yazgan'ın Türk Dünyasıyla ilgili başka bir eğitim etkinliği, kadın ve gençlere yöneliktir. 1999'da, otuz yedi Türk ülke ve topluluklarından kadın ve gençlerin katılımıyla birincisi gerçekleştirilen, sonraki yılarda da tekrarlanarak kurumsallaşan Türk Dünyası Kadın Kurultayı, Sosyal Güvenlik Kurultayı ve Türk Dünyası Gençlik kurultayı gibi Kurultaylar düzenlemiştir (Kadığlu, 2005).

14. Türkiye merkezli ortak bir kültür oluşturmayı amaçlayan eğitim etkinliği, Türk Dünyası ülke ve topluluklardaki liselerde verilen kültür temelli dersleri verecek öğretmenlerin, vakıf aracılığıyla 
Türkiye'den getirilmesidir. Örneğin, Azerbaycan'da bir, Kazakistan'da iki, Tataristan'da üç olmak üzere; toplam altı Lisedeki Türkiye Türkçesi ile özgürlük ve Türk kültürü konularını merkez alan Genel Türk Tarihi ve Din ve Ahlak Bilgisi Dersleri, Türkiye'den gelmiş idealist öğretmenler tarafindan; dile, düşüncede ve işte birlik ilkelerine göre verilmektedir (Yazgan, 2005). Bu eğitim etkinliğinin yapılması, sürekli şekilde gerçekleştiğinden kurumsallaşmıştır.

15.Yazgan, Türk Dünyası ülke ve topluluklarını tanımak, tanıtmak ve bu alanda çalışanları teşvik etmek ya da kısaca, kendimizi kendimiz tarafindan yapılacak araştırmalarla öğrenmek ve buna yardımcı olmak şeklindeki amacını gerçekleştirmek için yayınevleri oluşturmuştur. Bu yayınevleri aracılığıyla da, söz konusu Türk Dünyası ülke ve topluluklarında, Türk Milli Kültürü ile ilgili kitaplar basmış ve dergiler yayınlamıştır (Erkal, 2005). Örneğin, Türk Dünyası Tarih ve Kültür Dergisi, Ocak 1987'den itibaren her ay düzenli şekilde çıkartılıp, devamlılık kazandırıldığından kurumsallaşmıştır. Yine aynı şekilde, Türk Dünyası ülke ve toplulukları ile ilgili her konudaki araştırmaları, uluslararası bilimsel niteliklere göre kabul edip yayınlamayı amaçlamış Türk Dünyası Araştırmaları Dergisi, Ocak 1989'dan itibaren her ay düzenli olarak çıkartıldığından devamlılık kazanmış ve kurumsallaşmıştır (http://www.turan.org.tr).

\section{Sonuç}

Türk Dünyası ülke ve topluluklarının bulunduğu coğrafyada, eğitimle ilgili her tür etkinlikleri kurumsallaştırma düzeyine çıkartan Turan Yazgan; Türk kültür hayatında, neyin "en düşük maliyetle“ ve "en verimli şekilde", nasıl yapılacağını, bizzat yaparak göstermiştir. Kısaca, Kırım Türklerinden İsmail Gaspıralı'nın, Rusya baskısı nedeniyle gerçekleştirmediği, Türk Milliyetçiliği’ni temel alan, Dilde, Fikirde, İște Birlik düşüncesi; Cumhuriyet'in kuruluş yılları eğitim sosyologu, Ziya Gökalp tarafından da, zamanının koşulları gereği uzak ideal şeklinde ifade edilmiştir. Gaspıralı'nın ileriye sürdüğü düşünceyi hayata geçirmek kıvılcımı için, Turan Yazgan'1 beklemek gerekmiştir.

Sonuç olarak, Türkiye'nin "düşük maliyetle" ve "kaliteli şekilde", "nasıl eğitim yapması gerektiği”, Yazgan tarafından gerçekleştirilmiş uygulamalarla, somut şekilde belirtilmiştir. Dolayısıyla eğitimde verimlilik uygulamalarına, önce ülke içerisinde başlanılmalı, sonra Türk Dünyası ülke ve topluluklarına örnek model oluşturulmalıdır. Yazgan'ın eğitimle ilgili etkinlikleri, Türk Dünyası ülke ve topluluklarının eğitim beklentilerini karşıladığı için, Türkiye'den gelecek benzer girişimlere destek vermeye hazır olduklarını bildirmişlerdir. Örneğin, daha 1992'de, Tataristan Devlet Beşeri Bilimler Enstitüsü Rektörü ile Azerbaycan Rabita ve Enformasyon Teknolojileri Bakanı, Turan Yazgan öncülü̈̆̈̈ndeki etkinliklerle, Türk Dünyası ülkelerinde hem eğitim, hem milletlerarası münasebetlerin gelişip güçlendiği, kendilerinin de buna katkı yapmaya hazır olduklarını bildirmişlerdir (Abbasov ve Gayfullin, 2005).

Akın'ın belirttiği gibi (2012), eğitimde yapılması gereken; Türk Dünyası sevdalısı, gönül, akı1 ve dava insan1, Prof. Dr. Turan Yazgan'ın 2012'de belirttiği bütün Milli Düşünce Merkezlerini bir araya getirdiğimizde, Türk Dünyası ile daha çok bütünleşebiliriz şeklindeki yol haritasını, Türk Dünyasında destek görmüş girişimini benimsemektir. Türk Eğitim Sistemini daha başarılı kılmak için, Yazgan'ın Türk Dünyası ülke ve topluluklarında uyguladığ1, maliyeti düşük, verimi yüksek eğitim politikas1, Türkiye'nin eğitimle ilgili karar merkezleri tarafından içselleştirilmeli ve kurumsallaştırılmalıdır.

\section{Kaynakça}

Abbasov, A. (2005). Prof. Dr. Ali Abbasov'un Prof. Dr. Turan Yazgan ile İlgili Düşünceleri, İstanbul Üniversitesi Sosyal Siyaset Konferanslart Dergisi, Prof. Dr. Turan Yazgan'a Armağan Özel 
Sayıs1, 49, 2005, 47-49. http://www.journals4free.com/link.jsp?1=32293365 (10/01/2014).

Akın, K. (2012). Yazgan Hoca Daima Gönüllerde, Yeniçă̆ Gazetesi, 03/12/2012; http://www.yg.yenicaggazetesi.com.tr/habergoster.php?haber=6344 (18/01/2014).

Alper, Y. (2005). Turan Yazgan ile Üniversite ve Türkiye Üzerine Bir Sohbet, İstanbul Üniversitesi Sosyal Siyaset Konferansları Dergisi, Prof. Dr. Turan Yazgan'a Armă̆an Özel Sayısı, 49, 2005, 65-90. http://www.journals4free.com/link.jsp?l=32293365 (10/01/2014).

Atlı̆̆, N. (2005). Yazgan İçin, İstanbul Üniversitesi Sosyal Siyaset Konferansları Dergisi, Prof. Dr. Turan Yazgan'a Armağan Özel Saylst, 49, 2005, 1-2. http://www.journals4free.com/link.jsp?l=32293365 (13/01/2014).

Erkal, Mustafa E. (2005). Prof. Dr. Turan Yazgan Hocamız ve Bazı Anılar, İstanbul Üniversitesi Sosyal Siyaset Konferansları Dergisi, Prof. Dr. Turan Yazgan'a Armăgan Özel Saylsl, 49, 1519. http://www.journals4free.com/link.jsp?l=32293365 (13/01/2014).

Gayfullin, V. G. (2005). Bilim ve Faaliyet Adam1, Organizatör, Istanbul Üniversitesi Sosyal Siyaset Konferanslarl Dergisi, Prof. Dr. Turan Yazgan'a Armağan Özel Saylst, 49, 2005, 1-2. http://www.journals4free.com/link.jsp?1=32293365 (13/01/2014).

Gökçen, M. A. (2005). Hocamız, Dostumuz ve Ağabeyimiz Profesör Dr. Turan Yazgan, İstanbul Üniversitesi Sosyal Siyaset Konferanslarl Dergisi, Prof. Dr. Turan Yazgan'a $\begin{array}{lllll}\text { Armağan } \quad \text { Özel } & \text { Sayisl, } & 49, & 2005, & 7-14 .\end{array}$ http://www.journals4free.com/link.jsp?1=32293365 (15/01/2014).

Kadığlu, M.(2005). Yeni Yüzyılın İsmail Gaspıralı'sı Prof. Dr. Turan Yazgan, Ístanbul Üniversitesi Sosyal Siyaset Konferanslarl Dergisi, Prof. Dr. Turan Yazgan'a Armă̆an Özel Sayısl, 49, 2005, 53-65. http://www.journals4free.com/link.jsp?1=32293365 $(15 / 01 / 2014)$.

Kerimov, H. (2012). Türk Dünyasına Adanan Bir Ömür: Prof. Dr. Turan Yazgan (19382012), Ege Üniversitesi Türk Dünyası Incelemeleri Dergisi, 12/2, Kış 2012, 591-593. http://egeweb.ege.edu.tr/tdid/files/dergi_12/Vefeyât-TuranYazgan.pdf (15/01/2014)

Mamasidikov, A. (2005). Turan Yazgan: Türk Milletinin Gururu, Ístanbul Üniversitesi Sosyal Siyaset Konferansları Dergisi, Prof. Dr. Turan Yazgan'a Armağan Özel Sayısı, 49, 2005, 3941. http://www.journals4free.com/link.jsp?1=32293365 (15/01/2014).

Merdamert, M. H. (2014). Mefkûre, http://www.mirhaber.com/artikel.php?artikel id=1719 $(18 / 01 / 2014)$.

Toktomamatov, Ş. K. (2005). Kırgızistanlıların Gözüyle Turan Yazgan, İstanbul Üniversitesi Sosyal Siyaset Konferansları Dergisi, Prof. Dr. Turan Yazgan'a Armağan Özel Sayıs1, 49, 2005, 35-38. http://www.journals4free.com/link.jsp?l=32293365 (18/01/2014). 
Ünlü, S. (2005). Turan Yazgan Hoca ve Türk Dünyası, İstanbul Üniversitesi Sosyal Siyaset Konferanslarl Dergisi, Prof. Dr. Turan Yazgan'a Armağan Özel Saylsl, 49, 2005, 3133. http://www.journals4free.com/link.jsp?1=32293365 (18/01/2014).

Yazgan, T. (2005). Türkiye'nin Türk Dünyasındaki Eğitim - Öğretim Faaliyetleri, İstanbul Üniversitesi Sosyal Siyaset Konferansları Dergisi, 31, 2005, 13-35. http://www.journals.istanbul.edu.tr/tr/index.php/iktisatsosyoloji/article/view/5926 $(18 / 01 / 2014)$.

Yörük, A. (2005). Prof. Dr. Turan YAZGAN ya da Çağdaş Gaspıralı İsmail Bey, İstanbul Universitesi Sosyal Siyaset Konferansları Dergisi, Prof. Dr. Turan Yazgan'a Armağan Özel Saylsl, 49, 2005, 21-27. http://www.journals4free.com/link.jsp?1=32293365 (16/01/2014).

Zaim, S. (2005). İsmail Gaspiralı'dan Turan Yazgan'a, İstanbul Üniversitesi Sosyal Siyaset Konferansları Dergisi, Prof. Dr. Turan Yazgan'a Armağan Özel Saylsı, 49, 2005, 3-5. http://www.journals4free.com/link.jsp?l=32293365 (16/01/2014).

http://www.habererk.com/haber/35330/turan-yazgan-kimdir.html (18/01/2014).

http://www.turan.org.tr (18/01/2014).

http://tr.vikipedia.org/wiki/Turan_Yazgan (18/01/2014).

http://www.biyografi.net/kisiayrinti.asp?kisiid=4452 (18/01/2014).

http://www.turksoy.org.tr (18/01/2014).

Prof. Dr. Nihat Aycan
Muğla Sitkı Koçman Üniversitesi Eğitim Fakültesi E-mail: nihataycan@mu.edu.tr 